\title{
Report of Summer Meeting at Cypress Hills, June 15-16 '57
}

By MARGARET BELCHER, Corresponding Secretary

The third summer meeting of the Saskatchewan Natural History Society, held at the Cypress Hills on June 15 and 16, had a larger attendance than either of the two previous meetings. Over 100 registered from 34 points in Saskatchewan, Alberta, Manitoba, Ontario, South Dakota and California.

Field trips were the main feature of the programme of the two days meet. They included:

(1) Saturday morning excursion on foot, led by S. A. Mann, to familiarize the group with the Park, with comment on the flora of the Park by A. C. Budd, B. De Vries, and G. F. Ledingham.

(2) Saturday afternoon excursion by car to the Lookout and Bald Butte. This replaced the scheduled trip to the West Block cancelled because of rain and had roads. One party, travelling by jeep with the Conservation Officer, did get to the West Block on Sunday to see the Trumpeter Swans, and we have Frank Roy's account of the expedition

(3) Sunday morning birding trip by car to Cypress Lake.

An evening programme was held Saturday at Camp Shagabec. Mem. bers were welcomed by the President, Frank Brazier, and by the Editor G. F. Ledingham. Dr. Ledingham introduced Herman F. Chapman, former editor of the South Dakota Bird Notes who had come with his wife from Sioux Falls, S. D., to attend our meeting. Bruce McCorquodale of the Museum gave an illustrated talk on the fossil mammals of the Cypress Hills, Ralph Stueck of Abernethy showed coloured ifilm, and recording: of bird calls were played. After the programme, lunch was served in the camp hall.

Special thanks are due the local members who worked with the programme convener, Dr. R. W. Nero, to make the meet a success. Mr and Mrs. Mann of Skull Creek, with their neighbours and friends, playe host to the visitors, assisted with arrangements for the programme, anc planned the social evening and lunch at Camp Shagabec. George MacMillar of Maple Creek assisted Mr. Mann in organizing the excursions.

Leadership for the birding excursion to Cypress Lake was provide by Dr. H. Jenner of Fort San and F. G. Bard and R. W. Nero of the Museum to whom the society also wishes to express its appreciation.

Finally, we want to thank the United Church at Maple Creek for th use of Camp Shagabec, and Mr. C. S. Kerr at the Park for his untirin efforts in providing pleasant accommodation for our large group.

\section{Operation Trumpeter}

By FRANK ROY, Saskatoon

Our trip by Land-Rover to the West Block on Sunday, June 16, was indeed a thrilling one-the roads were next door to impossible; we had to be pulled out once by tractor-but what a pleasure to find the Trumpeters!

Bottley's Lake is an insignificant prairie lake with grassy shores and a marsh at the south end. It lies just at the eastern edge of the west block of the Cypress Hills which rise abruptly at this point to an elevation of well over 4,000 feet. We stopped at a rancher's place to determine which lake the Trumpeters were frequenting at the moment, since we were aware of the fact that the remove to Adam's Lake every sum mer when the cygnets are old enoug to stand the walk. They told us tha they were still at Bottley, and the they had five young.

When they reached the lake, th two old birds were in full view, an trailing them were seven youngchecked carefully with our $20 \mathrm{x}$ tele scope. They were across the lak from us, and we never did get ver close to them. One other adult h: remained on the lake this year, an it followed us as we drove to th north end of the lake. So the tot: count was 10 , three adults and seve 
ung. Richard Zapt was as pleased we were, and says that this is the st time that more than two adults ve been noted at the lake. Dr. rnatt took a number of pictures th his $400 \mathrm{~mm}$ telephoto lens, alcugh we doubt that in any of these 11 one be able to pick out all seven the young. For purposes of the ord, the observers were Dr. $H$. rnett, Dr. R. Bremner, Bob Pravda, chard Zapf (Conservation Officer), d myself.

Dther records of almost equal inest from Bottley's Lake include 10 ult Canada Geese accompanied by downy young - these at the northend of the lake; three Red-necked rbe (one of them sitting on a nest the west shcre of the lake), not eviously recorded from the Cypress lls area; and two pairs of Ringcked Ducks which Godfrey does list in his publication.

\section{st of Birds Recorded at the mmer Meeting in the Cypress ills, June 15-16, 1957}

The following birds were recorded the observers at the summer meetof the Saskatchewan Natural stcry Society in the Cypress Hills une $15-16,1957)$. Observers recded birds seen as they travelled m Maple Creek into the Park and trips to Cypress Lake and Boty's Lake as well as in the Park itf. The area covered, however, was as extensive as the area included W. Earl Godfrey's Birds of the press Hills and Flotten Lake Rens, Saskatchewan (Ottawa, 1950). rds not listed by Godfrey for the press Hills region are printed in lics.

As pointed out by Godfrey, the inest of the area for birders lies in variety of ecological communities $d$ in the affinity of the bird fauna the higher parts of the area with at of the Rocky Mountains. Such pically western species as the right's Flycatcher, Rocky Mounn Orange-crowned Warbler, Red ossbill, Audubon's Warbler, and nk-sided Junco occur in the press Hills; whereas Canada Jays, ruce Grouse and Brown-capped iickadees, so common in the conious forests of central and northern skatchewan, do not occur here at

irds recorded (i.e. seen or heard by one more observer)

ed-necked Grebe, Horned Grebe, Eared
Grebe, Western Grebe, White Pelican, Great Blue Heron, American Bittern, Trumpeter

Swan, Canada Goose, Mallard, Gadwall, Baldpate, Pintail, Shoveller, Blue-winged Teal, Redhead, Ring-necked Duck, Lesser Scaup, American Merganser, Cooper's Hawk, Redtailed Hawk, Swainson's Hawk, Ferruginous Hawk, Marsh Hawk, Pigeon Hawk, Sharptailed Grouse, Sage Grouse, Sora Rail, Coot, Killdeer, Wilson's Snipe, Long-billed Curlew, Willet, Spotted Sandpiper, Pectoral Sandpiper, Marbled Godwit, Wilson's Phalarope, California Gull, Ring-billed Gull, Franklin's Gull, Common Tern, Black Tern, Mourning Dove, Herned Owl, Long-eared Owi, Nighthawk, Belted Kingfisher, Yellow-shafted Flicker, Redshafted Flicker, Hairy Woodpecker, Downy Woodpecker, Eastern Kingbird, Arkansas Kingbird, Wright's Flycatcher, Horned Lark, Bank Swallow, Rough-winged Swallow, Barn Swallow, Cliff Swallow, American Magpie, Crow, Black-capped Chickadee, Red-breasted Nuthatch, House Wren, Catbird, Brown Thrasher, Robin, Olive-backed Thrush, Wilson's Thrush, Mountain Bluebird, Sprague's Pipit, Cedar Waxwing, Loggerhead Shrike, Starling, Orangecrowned Warbler, Yellow Warbler, Audubon's Warbler, Ovenbird, Macgillivray's Warbler, Yellow-thrcat, House Sparrow, Bobolink, Westtern Meadowlark, Yellow-headed Blackbird, Red-winged Blackbird, Brewer's Blackbird, Baltimore Oriole, Cowbird, Lazuli Bunting, Pine Siskin, Goldfinch, Red Crossbill, Spotted Towhee, Savannah Sparrow, Vesper Sparrow, Lark Sparrow, Pink-sided Junco, Chipping Sparrow, Clay-colored Sparrow, Song Sparrow, McCown's Lengspur.

\section{List of Persons Registered at the Cypress Hills Meeting}

Joyce Gunn, W. Anaka, of Spirit Lake; K. E. Baines of Tisdale; Mrs. Lucille Jenkins of Assiniboia; J. B. Belcher of Dilke; Mr. and Mrs. E. Symons, Mrs. M. Shaw, Mrs. H. Phillips of Rocanville; Mr. and Mrs. Charles Prince, Bobby Barradell, Donna Barradell, Kenneth Thompson Keith Thompson, of Paradise Hill; Mr. and Mrs. G. C. Buchanan of Francis; R. P. Stueck of Abernethy; Mr. and Mrs. B. DeVries of Fort Qu'Appelle; Dr. H. D. Jenner, R. A. Nevard of Fort San; Mr. and Mrs. Fred Beveridge, $\mathrm{Mr}$. and Mrs. G. MacMillan, Mr. and Mrs. L. I. Binkley of Maple Creek; Mr. and Mrs. S. A. Mann, R. Mann, Mrs. I. Bennetto of Skull Creek; Kate Shuard of Carnagh; Pat Long of Melfort; Mr. and Mrs. S. Jordheim of White Bear; M. O. Bakken, Mrs. Laura Wright of Bracken; L. Martinovsky, T. Martinovsky, Mr. and Mrs. F. Hermansky of Gerald; Mr. and Mrs. J. C. Nichol, J. McGladdery of Marsden; W. W. Graham of Lloydminster; Mr. and Mrs. G. R. Binkley of Shaunavon; Mr. and Mrs. A. C. Budd, Mr. and Mrs. J. R. Caldwell of Swift Current; $\mathrm{Mr}$ and Mrs. Howarth of Prince Albert; Mr. and Mrs. A. C. Ellis, Mrs. F. B. Taylor, Dr. E. K. Schue, U. E. Steele of Moose Jaw; 
J. Shadick, Mr. and Mrs. J. D. Hogg, Betty Long, Helen, Mann, F. Roy, R. Pravda, Dr. R Bremner, Mrs. M. Evans of Saskatoon; Mr. and Mrs. B. Knox, E. Good, W. Baker, Mr. and Mrs. L. McK. Robinson, Dr. Frances McGill, Mrs. J. C. Black, Mrs. R. Williams, Gertrude Murray, Thelma Brady, Mrs. M. Willers, Marguerite Robertson, F. G. Bard, B. C. Shier, B. McCorquodale, Joyce Dew, Helen Rempel, Frances McKay, Wolfram Niessen, Mr. and Mrs. R. W. Fyfe, Dr. and Mrs. R. W. Nero, Dr and Mrs. G. F. Ledingham, Mrs. E. Cruick- shank, Dr. Lucy Murray, Mrs. G Hodgins, Edna Colbeck, Kay Armstrong, Margaret Belcher, W. A Silverthorn, Mr. and Mrs. D. Gilroy cif. Regina.

OUTSIDE SASKATCHEWAN:

Mr. and Mrs. L. H. Stokes of Winnipeg; W. Crossley, Grandview, Man T. Dutton, Gilbert Plains, Man.; Mr and Mrs. E. Robinson, Wawanesa Man.; L. M. Lohr, Erskine, Alta. Kathleen Hodges, A. Hodges, Calgary D. H. Barnett, Toronto; Mr. and Mrs Herman F. Chapman, Sioux Falls S. D.; S. A. Stueck of Ventura, Cal

\section{S.N.H.S. SUMMER MEETING AT EMMA LAKE}

The Saskatchewan Natural History Society has been invited by the Prince Albert Natural History Society to hold its 1958 summer meeting at Emma Lake.We are pleased to accept the invitation of the P. A. society, and we suggest that you plan now to be at Emma Lake next summer.

\section{The BLUE JAY Bookshelf}

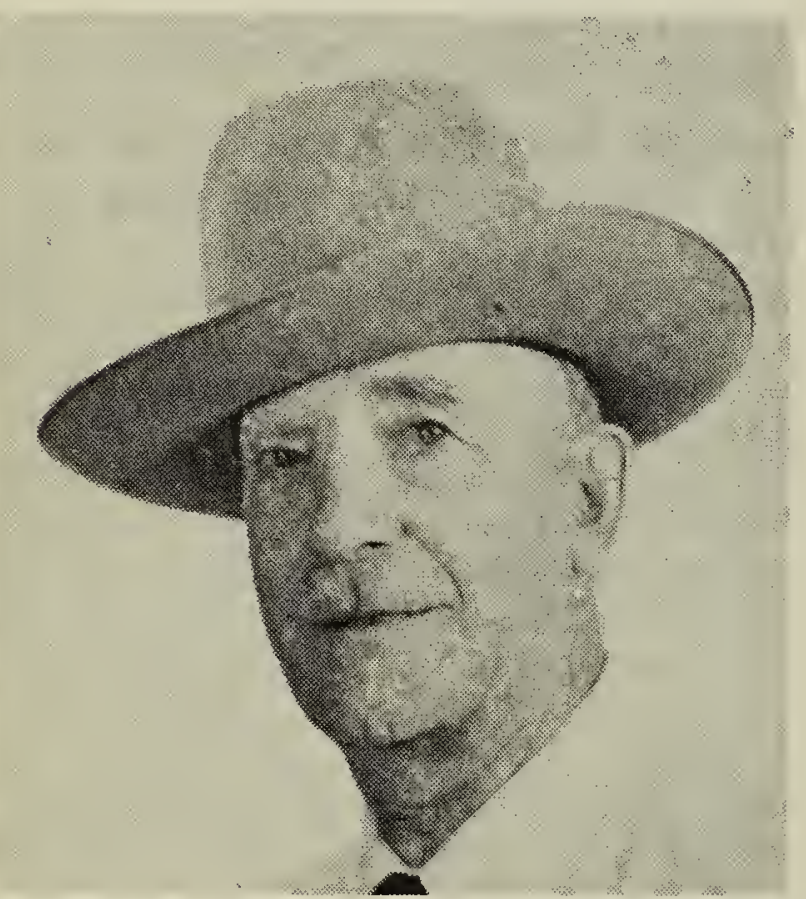

Wild Plants of the Canadian Prairies

By A. C. Budd. Publication No. 983, Canada Department of Agriculture, Ottawa, 1957. $\$ 1.50$.

This is a revision in more convenient format of the mimeographed publication "Wild Plants of the Farming and Ranching Areas of the Canadian Prairies," Ottawa, 1952. As such, it remains the only usable flora of the Canadian Prairies. Those of us who had to learn to recognize our plants 'from Rydberg's confusing and often misleading writings wlll know what a need it fills. It could be, even, that the author has not been quite ruthless enough in eliminating the Rydbergian phoney species I notice a few left in Aster, for example.
The keys seem eminently work. able. Some people have regretted the necessity for keys saying, "Wh: aren't there more pictures? Thi answer is that when over 1201 species are to be described there $\mathrm{i}$ : no escape from written keys. Thi author has taken pains, as he says, ti keep the language as simple anc non-technical as possible; but a cer. tain amount of work is yet requirer from those who would use this book The utter novice would be well ad. vised to begin by going over care fully the introductory material - th diagrams and descriptions of plan parts and the directions for using th keys. This explanatory text, on notes, has been enlarged and trans ferred to the front of the book in th new edition. Perhaps in the writtes text special mention might have bee made of some plants which are har to key out, e.g. a greenhorn coul have quite a time trying to decid if members of the Ragweed sub family have both calyx and coroll in the flowers.

The printing is clear and the lin drawings (by the author) have charming quality. There are 6 species shown in the drawings; the number should give the novice foothold from which to study furthe: A hard cover might have been use ful, considering the field usage man copies are destined for. - John $F$ Hudson, Regina. 